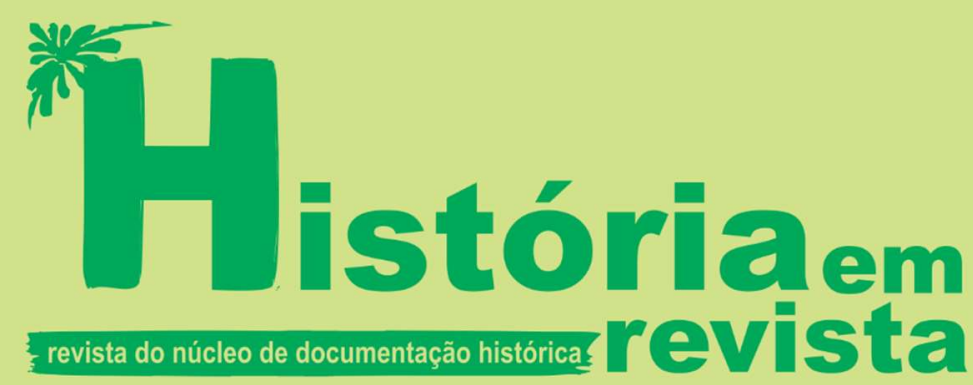

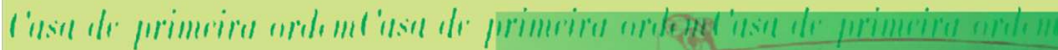

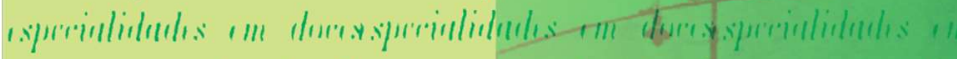

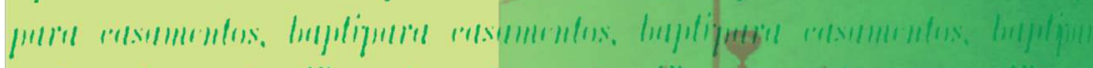

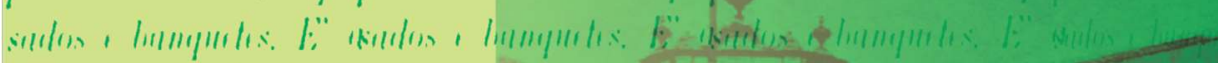

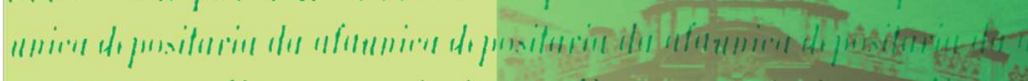

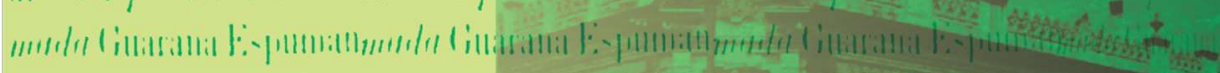

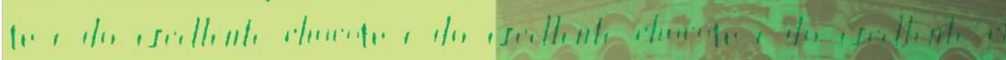

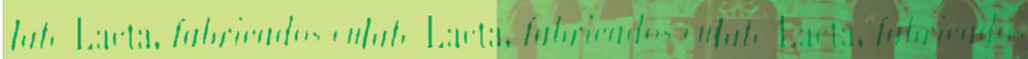

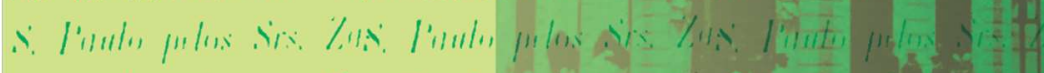

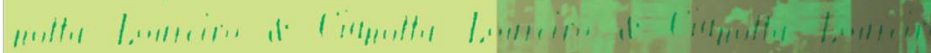

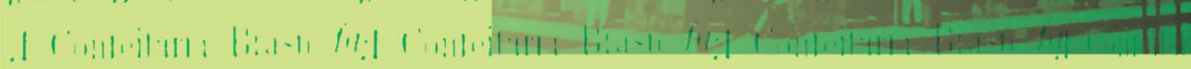




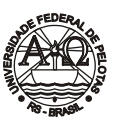

Obra publicada pela Universidade Federal de Pelotas Reitor: Pedro Rodrigues Curi Hallal Vice-Reitor: Luis Isaías Centeno do Amaral

Chefe de Gabinete: Aline Elias Lamas

Pró-Reitor de Graduação: Maria de Fátima Cóssio

Pró-Reitor de Pesquisa e Pós-Graduação: Flávio Fernando Demarco

Pró-Reitor de Extensão e Cultura: Francisca Ferreira Michelon

Pró-Reitor de Planejamento e Desenvolvimento: Otávio Martins Peres

Pró-Reitor Administrativo: Ricardo Hartlebem Peter

Pró-Reitor de Infra-estrutura: Julio Carlos Balzano de Mattos

Pró-Reitor de Assuntos Estudantis: Mário Renato de Azevedo Jr.

Pró-Reitor de Gestão Pessoas: Sérgio Batista Christino

\section{CONSELHO EDITORLAL}

Representante das Ciências Agronômicas: Guilherme Albuquerque de Oliveira Cavalcanti (Titular), Cesar Valmor Rombaldi (suplente) e Fabrício de Vargas Arigony Braga (suplente) | Representantes da Área das Ciências Exatas e da Terra: Adelir José Strieder (titular) e Juliana Pertille da Silva (suplente) | Representante da Área das Ciências Biológicas: Raquel Ludke (suplente) | Representante da Área das Engenharias e Computação: Darci Alberto Gatto | Representantes da Área das Ciências da Saúde: Claiton Leoneti Lencina (titular) e Giovanni Felipe Ernst Frizzo (suplente) | Representante da Área das Ciências Sociais Aplicadas: Célia Helena Castro Gonsales | Representante da Área das Ciências Humanas: Charles Pereira Pennaforte e Guilherme Camargo Massaú (suplente) | Representantes da Área das Linguagens e Artes: Josias Pereira da Silva (titular) e Maristani Polidori Zamperetti (suplente)

\section{INSTITUTO DE CIÊNCLAS HUMANAS}

Diretor: Prof. Dr. Sidney Gonçalves Vieira

Vice-Diretor: Prof. Dr. Sebastião Peres

\section{NÚCLEO DE DOCUMENTACÃO HISTÓRICA}

Coordenadora:

Prof ${ }^{a}$ Dra. Lorena Almeida Gill

Membros do NDH:

Prof ${ }^{a}$ Dra. Beatriz Ana Loner

Prof ${ }^{a}$ Dra. Lorena Almeida Gill

Prof. Dr. Paulo Ricardo Pezat

Prof. Dr. Aristeu Elisandro Machado Lopes

Técnico Administrativo:

Paulo Luiz Crizel Koschier

HISTÓRIA EM REVISTA - Publicação do Núcleo de Documentação Histórica

Comissão Editorial:

Prof. Dr. Aristeu Elisandro Machado Lopes

Prof ${ }^{a}$ Dra. Beatriz Ana Loner

Prof ${ }^{a}$ Dra. Lorena Almeida Gill

Prof. Dr. Paulo Ricardo Pezat

Conselho Editorial:

Prof ${ }^{a}$ Dra. Helga I. Landgraf Piccolo (UFRGS)

Prof. Dr. René Gertz (UFRGS) (PUCRS)

Prof. Ms. Mario Osorio Magalhães (UFPel)

Prof. Dr. Temístocles A. C. Cezar (UFRGS)

Profa. Dra. Beatriz Teixeira Weber (UFSM)

Prof ${ }^{a}$. Dra. Maria Cecília V. e Cruz (UFBA)

Prof. Dr. Marcelo Badaró Mattos (UFF)

Profa. Dra. Joan Bak (Univ. Richmond - USA)

Prof. PhD Pablo Alejandro Pozzi (Universidad de Buenos Aires).

Prof. Tommaso Detti (Università Degli Studi di Siena)

Editor: Prof. Dr. Aristeu Elisandro Machado Lopes

Editoração e Capa: Paulo Luiz Crizel Koschier

Editora e Gráfica Universitária

R Lobo da Costa, 447 - Pelotas, RS - CEP 96010-150 |

Fone/fax: (53) 32278411

e-mail: editora@ufpel.edu.br

\section{Impresso no Brasil}

Edicão: 2017

ISSN - 1516-2095

Dados de catalogação na fonte: Aydê Andrade de Oliveira - CRB - 10/864

História em revista / publicação do Núcleo de Documentação Histórica. Instituto de Ciências Humanas. Universidade Federal de Pelotas. v.23, (dez. 2017). - Pelotas: Editora da UFPel, 2017.

$1 \mathrm{v}$.

Anual

ISSN 1516-2095

1. História - Periódicos. I. Núcleo de Documentação Histórica. Instituto de Ciências Humanas. Universidade Federal de Pelotas. CDD 930.005

\section{Indexada pela base de dados Worldcat Online Computer Library Center}

\section{PEDE-SE PERMUTA} WE ASK FOR EXCHANGE

UFPel/NDH/Instituto de Ciências Humanas

Rua Cel. Alberto Rosa, 154

Pelotas/RS - CEP: 96010-770

Caixa Postal 354

Fone: (53) 32843208

\section{http://wp.ufpel.edu.br/ndh/} e-mail:ndh.ufpel@gmail.com 


\title{
Do PuChirâo do Gé Picaço a Terra dos Pinheiraes: OPERAÇÕES DE SELEÇÃO DA HISTÓRIA, DA MEMÓRIA E DO IMAGINÁRIO DE PASSO FUNDO NA DÉCADA DE 1920
}

\author{
From PUCHIRÃO DO GÉ PICAÇO TO TERRA DOS PINHEIRAES: HISTORY'S \\ OPERATIONS OF SELECTION, OF PASSO FUNDO'S MEMORY AND IMAGINARY IN \\ THE '20S
}

Eduardo Roberto Jordão Knack ${ }^{1}$

\begin{abstract}
Resumo: O presente trabalho objetiva esclarecer as operações de seleção da história, da memória e do imaginário de Passo Fundo a partir de duas obras produzidas na década de 1920: O Puchirão do Gé Picaço, livro de poemas escrito pelo advogado e jornalista Francisco de Paula Lacerda de Almeida Júnior, e Terra dos Pinheiraes, escrito pelo historiador Francisco Antonio Xavier e Oliveira. A partir de uma análise detalhada dessas duas obras, é possível perceber diferentes narrativas que estabelecem diferentes formas de filiação com o passado, bem como os sujeitos, lugares e acontecimentos importantes para essas distintas formas de relação com a história e a memória da cidade. Essas escolhas foram operadas a partir de um regime de historicidade característico daquele contexto, marcado pelo progresso e pela modernização urbana, o que influenciou na afirmação e no sucesso de uma forma de escrita da história municipal.
\end{abstract}

Palavras-chave: História. Memória. Narrativa.

\section{Considerações iniciais}

O presente trabalho é dedicado a analisar duas obras, uma literária e uma histórica, que apresentam diferentes perspectivas de filiação ao passado. Uma prosperou, legitimando certos elementos como componentes centrais da história de Passo Fundo, enquanto a outra não encontrou espaço nas produções historiográficas durante a maior parte do século XX promovidas pelos "produtores autorizados" da memória local (CANDAU, 2011, p.124), encarregados da transmissão de um capital de lembranças de acordo com sua visão de mundo. Ao ignorar uma dessas obras os guardiões da memória do município de Passo Fundo/RS optaram pelo esquecimento de uma visão de mundo, de um modo de inteligibilidade que não condizia com a posição de uma cidade moderna e progressista do norte do estado do Rio Grande do Sul. Objetiva-se nesse artigo uma análise de como essa operação foi efetivada em duas obras, como certos personagens, acontecimentos e lugares foram

${ }^{1}$ Doutor em História pela Pontifícia Universidade Católica do Rio Grande do Sul; PósDoutorando pelo Programa de Pós-Graduação em Memória Social e Patrimônio Cultural - UFPel. E-mail: eduardorik@yahoo.com.br 
abordados pelos autores em questão, observando como história, memória e imaginário, engendrados por um determinado regime de historicidade, estão articulados em uma narrativa literária e historiográfica.

Para Nicolazzi (2003, p.2), a noção "regimes de historicidade" (HARTOG, 2013) "permite conceber um espaço de possibilidades para se pensar historicamente, delineando certos limites para o pensamento e, consequentemente, definindo os possíveis locais de ruptura". Ao efetuar uma operação de seleção de sujeitos, lugares e acontecimentos que caracterizam a história de uma comunidade, entram em jogo as expectativas em relação ao futuro, que dependem em grande medida de como essa sociedade olha para o passado. Em Passo Fundo, durante o século XX, prevaleceu uma determinada visão do passado que privilegiou a seleção de temas, personagens, acontecimentos e lugares relevantes para história tendo a obra de Xavier e Oliveira como fundamental referência, em particular, Terra dos Pinheiraes de 1927.

A obra O Puchirão do Gé Picaço, de Julio Simão publicado em 1925 pela Livraria Nacional em Passo Fundo, preocupa-se em formular algumas considerações sobre o "tipo etnológico" que formou-se no planalto. Para o autor, o "homem brasileiro" próprio da região norte do estado era o caboclo, grupo social que praticamente desaparece das obras sobre a história da cidade nas comemorações do centenário e das publicações do "pai da história" do município (título conferido ao historiador Xavier e Oliveira). O presente trabalho considera essas duas obras, publicadas na segunda metade de 1920, como um momento decisivo na construção da história e da memória de Passo Fundo. Enquanto uma perspectiva sobre o passado prosperou e foi difundida na cidade, outra não encontrou espaço. Com isso, sujeitos, lugares e sociabilidades foram afirmados, aparecendo nas páginas da história, enquanto outros foram esquecidos e/ou ignorados. Nesse sentido, uma análise detalhada dessas obras é necessária para exemplificar as diferenças entre ambas.

\section{O Puchirão do Gé Picaço}

A dissertação de Ribas (2007, p.47), dedicada a uma análise das representações gauchescas em Passo Fundo, evidencia o descaso com a obra $\mathrm{O}$ puchirão do Gé Picaço pelos movimentos tradicionalistas locais que se baseiam, em seus discursos, nos trabalhos de Xavier e Oliveira, não apenas suas publicações sobre a história municipal, mas também em seus poemas publicados, como exemplo o autor cita os livros Pelo passado e Cartas gaúchas, deixando "evidente a disparidade entre Almeida Junior e Xavier e 
Oliveira na escolha do tipo humano a ser tomado como referência gentílica." Ayres (2008, p.27-28), que empreendeu uma pesquisa sobre Almeida Junior (que adota o pseudônimo de Julio Simão), mostra que, mesmo na época da publicação do poemeto serrano, embora tenha tido o lançamento noticiado pelo jornal O Nacional em 30 de dezembro de 1925 (um dos periódicos de circulação diária no município), a imprensa "não escreveu uma linha sobre o autor e seu livro".

O advogado e jornalista Francisco de Paula Lacerda de Almeida Júnior (que escreve sob o pseudônimo de Julio Simão) chegou em Passo Fundo como correspondente de guerra em 1923 para um jornal em São Paulo, permanecendo na cidade até 1932. Monteiro (2010) define O Puchirão do Gé Picaço como "uma resposta ao Poemeto Gaúcho - Antônio Chimango", mostrando que o "biriba" (o tipo serrano) e o gaúcho "guardam diferenças fundamentais [...]. Enquanto resposta literária, o Poemeto Serrano consiste na demonstração das dessemelhanças históricas, raciais e lingüísticas entre os homens da Serra e da Campanha"2. Para Almeida Júnior, a observação da vida do caboclo é importante, inicialmente, pelo desconhecimento que se tem dos homens e da vida na serra, o que leva a definição do homem do Rio Grande do Sul a ser pautada exclusivamente pela região sul do estado, a campanha gaúcha.

A campanha, a fronteira do nosso Estado têm sido vasculhadas, observadas,
estudadas pelos nossos literatos, em seus usos, costumes e tradições. Quanto á
Serra, se não ha descaso por ella, ha uma absoluta ignorancia da Terra e do
Homem. Não explico o phenomeno, porque, francamente, a vida do cabôco da
serra é bellíssima! O ambiente em que elle labora e vive tem encantos como as
stepes verdes do extremo sul do Rio Grande não suggerem. As mattas umbrosas
e perfumadas que o machado progressista, mas iconoclasta, do colono vae
talando aos poucos, têm outra belleza, suggerem outra inspiração que se não
soffre com a visada desse mar gaio que é o pampa sulino. O typo autocthone,
tambem é outro, radicalmente diverso o serrano do fronteiriço. (SIMÂO, 1925,
p.6).

Além da descrição do espaço habitado pelo "tipo social da serra", quando o autor se refere ao "machado, progressista, mas iconoclasta do colono", está atribuindo um determinado valor dúbio à ação desse personagem histórico. Ao mesmo tempo em que lhe atribui o adjetivo "progressista"

2 Para isso, o autor utiliza nos poemas a forma de falar própria do caboclo da serra e "emprega a velha quadra popular, num esquema bastante raro (ABBA), e sextilhas em ABBACC. A linguagem dos poemas também é radicalmente diferente: O Puchirão do Gé Picaço está muito próximo dos poemas sertanejos de Catulo da Paixão Cearense, à época extremamente populares". (MONTEIRO, 2010). 
(progresso entendido aqui como responsável pelo desenvolvimento econômico e urbano da região), também o classifica como iconoclasta, visto que destrói o habitat de um grupo que acabou à margem desse progresso, os caboclos. Esse dilema existente entre o mundo urbano e rural não é exclusivo de Passo Fundo ou mesmo do Rio Grande do Sul. Murari (2009, p.266), analisando o conto Banzo, de Coelho Neto, também identifica essa relação de duas vias entre as transformações trazidas pela modernidade, o progresso, e a consequente transformação da paisagem e dos espaços dos tipos sociais que o habitavam, pois a "destruição da natureza parecia ser uma consequência inevitável deste processo de crescimento em que os elementos de estabilidade", a própria natureza, "esfacelavam-se frente à expansão das áreas ocupadas pelo homem, às transformações impressas por novas formas de atividade e por novas relações econômicas."

A descrição do espaço presente em $O$ puchirão representa a opção por uma seleção, uma organização do mundo diferente da história municipal "oficial" legitimada a partir das obras de Xavier e Oliveira. O lugar onde se desenrolam os diversos "causos" do poema não é o mundo urbano, embora localizado próximo a Passo Fundo: "Pois foi naquelle districto,/ Distante da povoação,/ Que, durante um puchirão,/ Cheio de pinga e de grito,/ (A pinga do dono da roça,/ Os grito da gente da troça)" (SIMÃO, 1925, p.9). O mundo em que os caboclos vivem é marcado pela solidariedade, como alguns versos do poema sugerem, especialmente quando a palavra "puchirão" é explicada.

Justificando o título do livro, Simão (1925, p.12) aponta o puchirão como um costume muito antigo dos caboclos "Que é tão véio como o mundo/ E, com elle, profundo", que pode ser considerado um grande acontecimento, pois reúne muitos trabalhadores que, além da labuta no roçado, também se envolvem em atividades, em festas, bebedeiras, músicas e participam com os próprios causos contados, como os versos do personagem/narrador do livro, o caboclo. O puchirão seria uma espécie de mutirão para realizar algum trabalho (no caso, em uma plantação): "No dia do puchirão/ Chega todo o visindario,/ Ninguem não ganha salario/ É uma ajuda de irmão.../ Sómentes o dono da roçal Dá uma festa p'ra trósa,/ Quando acaba a prantação./ Se come churrasco e farinha,/ Corre a pinga e denoitinha/ Se dança e hai violão,/ E sempre hai desafio, Nem que chova e faça frio..." (SIMÃO, 1925, p.13-14). O puchirão é justificado a partir de comparações com o ambiente natural. Simão sugere, por exemplo, uma comparação com as estrelas, que sozinhas, não iluminariam quase nada, mas juntas dão luz à noite. Também utiliza exemplos com os predadores, quando menciona que os tigres e os guarás apanham apenas animais que se desgarram dos rebanhos, andando sozinhos pelas matas. 
Depois de descrever o lugar e o acontecimento que envolve a "caboclada" da região, bem como o valor inerente à ação que caracteriza o puchirão, Simão passa a descrever o personagem principal do encontro, o "tipo etnológico", o caboclo. O narrador descreve uma figura caricatural, de cabelos pretos "Que nem espinho de ouriço", com os olhos negros, "Num sembrante côr de cuia", com um corpo curvado, "C'as perna sempre cambota", taxado de feio, "Mas pau torto é que dá mel...". Esse caboclo, marcado no corpo pelo trabalho nas roças e nas matas, aprende o que sabe com as experiências da vida, considerada um livro aberto, mas encoberto para aqueles que não conhecem a lida, o trabalho. (SIMÃO, 1925, p.15). Essa construção está muito próxima daquela descrita por Ferreira (2002, p.69) em São Paulo nos Almanachs do final do século XIX, tendo o "caipira", associado ao "sertão" como uma designação "fabulosa dada as regiões mais longínquas do interior brasileiro, e no entanto cada vez mais próximas" em um momento de modernização onde diferentes grupos se encontravam (desenvolvimento das comunicações, ligações por estradas de ferro, etc.). Tanto o "caipira" como o "caboclo", do ponto de vista social, identificam uma série de sujeitos homens livres, pequenos agricultores, empregados nas fazendas, em caso mais específico do sul, indivíduos que viviam da colheita dos ervais e matas públicas (que estavam acabando nesse momento, o que reforça o sentimento de solidariedade), mas, da mesma forma como nos almanaques paulistas referidos por Ferreira, "não havia lugar para a cultura negra."

Nessa construção narrativa são descritos, inicialmente, o lugar, a serra nos arredores de Passo Fundo, os personagens, no caso, a figura do caboclo, e o acontecimento inicial que decorre da ação dos sujeitos, o puchirão, que já apresenta o valor implícito desse trabalho, a solidariedade entre moradores do interior, que embora simplórios, sem estudos e outros recursos próprios das cidades, são solidários uns com os outros e aprendem aquilo que necessitam a partir de suas experiências. Cabe destacar que esse livro, embora não tenha o objetivo ou a aspiração de se tornar uma obra de história (é um poema resposta), joga com uma historicização de sua narrativa (RICOEUR, 1997), na medida em que descreve um espaço geográfico localizado no interior de Passo Fundo, próximo ao município de Marau; um personagem (o caboclo), que mesmo descrito de forma genérica, através da atribuição de algumas características a todo um grupo social, pode ser identificado como sujeito histórico, existente não apenas na imaginação do poeta, mas como habitante da região serrana; e um acontecimento (o puchirão) peculiar e característico desse grupo.

O poema não remete apenas a uma construção fictícia, a região, o 
caboclo e o puchirão são elementos que existem e estão difundidos no cotidiano da região. Portanto, definir e diferenciar esse "caboclo" dos habitantes das cidades era muito difícil, para isso o autor apela "para os aspectos mais visíveis de uma suposta diferença cultural: os modos de falar e de vestir, os costumes, os gestos, as músicas." (FERREIRA, 2002, p.70) Ocorre o que Ricoeur (1997) classificou como uma "historicização da ficção", uma vez que os personagens podem não ter existido (nos causos contados, são feitas referências a sujeitos históricos, pessoas que existiam na sociedade do período, mas criam-se pseudônimos para esses indivíduos) e o puchirão descrito pode também não ter ocorrido. Não há como precisá-lo, datá-lo historicamente, mas eles existiam na década de 1920, embora idealizados, ficcionalizados na literatura. A semelhança com a definição do caipira paulista na passagem do século XIX para o XX na narrativa de Simão é marcante, pois, "embora bruto e ingênuo", também era visto como "fonte de sabedoria popular" que desaparecia no contexto de modernização urbana. (FERREIRA, 2002, p.71).

O caboclo do planalto médio rio-grandense também aparece como um personagem literário que encarna os valores da solidariedade e da simplicidade de uma vida campesina e em contato com a natureza. Também é importante colocar a temporalidade da obra em foco, pois apesar de se referir a um tipo social que existia na década de 1920, realizar datações, construir uma cronologia, não faz parte do objetivo da obra, o que estabelece uma forte relação com a imaginação. O puchirão descrito, desde os trabalhos na roça até as festas, bebedeiras, as músicas e a contação de "causos", pode muito bem relatar uma situação que esteja ocorrendo hoje no interior do planalto médio rio-grandense. Porém, esse tempo está intimamente associado com o espaço onde a história se desenrola, pois, como o autor adverte no início da obra, o "machado progressista" do colono põe em risco esse lugar idílico descrito na narrativa. Esse tempo é muito diferente da temporalização que imprime o ritmo da vida urbana, da sua aceleração, e principalmente de suas tentativas de domesticação a partir de relógios, calendários, cronologias históricas, etc. Trata-se de um tempo narrativo quase fora do tempo histórico.

Essas características, de acordo com Murari (2010, p.160), aproximam Almeida Junior (Julio Simão) da literatura regionalista que marcava o Rio Grande do Sul no início do século XX e que assumiu "relevância para a caracterização da heterogeneidade do país, para a representação dos grupos sociais marginais em relação ao processo de modernização produtiva" que marcava o Brasil. Ao incorporar "à cultura escrita uma proposta de registro das tradições comunitárias rurais" que se encontravam ameaçadas "em face do avanço da modernidade" (MURARI, 2010, p.160), da urbanização e da 
industrialização, esse gênero contribuiu para o conhecimento e preservação desse patrimônio simbólico de grupos que não possuíam outros meios para resguardar sua herança, seu modo de vida. Mas é necessário ressaltar que se trata de uma leitura de uma elite letrada, que pertencia ao mundo urbano e certamente isso influenciou suas descrições. De qualquer forma, grupos sociais que ainda não haviam aparecido na história oficial de Passo Fundo entram em cena a partir dessa literatura.

É importante salientar que a descrição do lugar, a explicação sobre o puchirão e a caracterização do caboclo é realizada por Julio Simão, depois os causos são contados por outros personagens do livro, é como se Almeida Junior estivesse lembrando em seus versos do que os outros contaram. Nesse sentido, o primeiro causo contado é narrado pelo personagem Chico Faria, trovador que conta a história do Cacimbinha. Esse causo em particular é também um exemplo de historicização da ficção. A narrativa, apesar de não trabalhar com datas, pode ser identificada com um determinado contexto, pois o personagem era chamado de Cacimbinha apelido (depreciativo) dado a um personagem político da década de 1920. Portanto, essa mudança de narrador, de Julio Simão descrevendo as belezas e as características da região a Chico Faria, que passa a contar um dos causos abordados no poema, implica uma alteração de percepção da temporalidade em virtude da aproximação com o contexto histórico. De um espaço idílico e atemporal, passa a ser construída uma crítica a um sujeito que atuava na política local, adentrando o tempo histórico, tornando o espaço temporalmente localizável, porém, toda a situação (o causo sendo contado durante o puchirão) ainda é fictícia, mesmo fazendo referência a acontecimentos e personagens históricos.

Para Ayres, Cacimbinha seria uma referência ao Dr. Ney de Lima Costa, natural de Taquari (RS), que estudou em Porto Alegre, mas residiu em Passo Fundo durante anos, atuando como advogado, jornalista e comerciante, e se envolveu em diferentes atividades políticas e sociais Almeida Junior teria um desafeto com Ney Lima Costa, cuja natureza não é conhecida plenamente, especula-se que se deve "a uma rixa do tempo da vida militar em Porto Alegre, quem sabe um preterimento de cargo, quiçá uma aversão pessoal, mas com certeza o ódio político partidário foi móvel do versejador gaúcho de sangue pernambucano". (AYRES, 2008, p.19). A história de Cacimbinha é contada de modo caricatural, em que o personagem é taxado de patife, espertinho, maroto, entre outros adjetivos negativos. (SIMÃO, 1925, p.18-19). Chico Faria resume a trajetória de Cacimbinha desde a infância, mostrando sempre suas espertezas, sua passagem na escola militar em Porto Alegre, seu cargo de Intendente Municipal (Ayres informe que Ney de Lima Costa foi Intendente 
de Pinheiro Machado em 1915, município anteriormente denominado Cacimbinhas).

Terminado essa parte do causo (pois havia anoitecido), o poema retoma a narrativa no segundo dia no puchirão (os causos eram contados ao final do trabalho, momento em que todos os trabalhadores se reuniam, depois de comer, beber e festejar). Simão retoma a narração, descrevendo o espetáculo do amanhecer na região serrana, o café da manhã servido pelo velho Gé (café com melaço e jacuba), o dia no roçado plantando milho e feijão, até o trabalho terminar, quando "Estava o sol se sumindo,/ Meu Deus, que dia tão lindo!” (SIMÃO, 1925, p.29). As características da região são retomadas na narração de Simão, retornando ao aspecto idílico e mesmo atemporal do cenário descrito, o que apela para a imaginação do leitor e do próprio narrador, que deixa explícita a dificuldade de descrever tamanha beleza, caracterizada como um carnaval de cores inexplicável.

Depois dessa descrição feita por Simão, entra em cena a narração de Chico Faria, retomando o causo do Cacimbinha. Cabe destacar, para o presente trabalho, a caracterização da vida do caboclo, sua relação e admiração pela natureza que o cerca, os valores expressados em suas ações, como demonstra a solidariedade na realização do puchirão para ajudar na roça do velho Gé. A trova que conta a história do Cacimbinha, além de ser uma crítica a uma desavença de Almeida Junior, também é uma crítica à esperteza que reinava no mundo político, próprio da vida nas cidades, o que contrasta fortemente com essa vida no interior, marcada pela simplicidade, pelo trabalho honesto e solidário e pelo apego à terra e à natureza. A defesa desses elementos pelo autor de o Puchirão do Gé Picaço também demonstra que os caboclos, com seus costumes rurais, constituíam uma possibilidade real de escolha e seleção para a escrita da história da cidade dentro do conjunto de alternativas da década de 1920. O quase desaparecimento desse grupo das páginas da história representa as seleções operadas pelas elites letradas passofundenses em virtude da conjuntura em que viviam e da experiência temporal que orientava sua visão sobre os encadeamentos possíveis entre as categorias temporais - passado, presente e futuro.

Essa seleção implicou um trabalho de esquecimento de outros grupos, acompanhado, mas esse silêncio não significa que esses grupos obliteraram sua consciência enquanto sujeitos históricos. Muitas dessas feridas afloraram nas portas do século XXI e ainda não foram plenamente sanadas3. A análise de $\mathrm{O}$

3 Alguns trabalhos que problematizaram a constituição do patrimônio históricoarquitetônico de Passo Fundo, apontaram essas feridas que afloraram no século XXI. 
Puchirão do Gé Picaço evidencia que, embora trate-se de um "poemeto" (poesias, e não uma narrativa histórica propriamente dita), estabelece uma forma diferente de filiação com o passado daquela adotada por Xavier e Oliveira. Cabe, no momento, identificar as visões, as formas de filiação que orientaram essas operações seletivas sobre os elementos que passaram a figurar como história e memória da região, em detrimento de outros, bem como ir mais além ao questionar a percepção sobre o tempo dos indivíduos que estavam na vanguarda dessas produções.

Catroga (2009, p.11) mostra como as atividades de anamnesi, a busca ativa de recordações pelos indivíduos, "remetem para a maneira como cada um se filia no seu próprio passado e como, explicitamente, constrói a sua identidade e se distingue dos outros." As duas obras (O Puchirão do Gé Picaço e Terra dos Pinheiraes) remetem a diferentes maneiras de filiação, de conexões estabelecidas com o passado pelos respectivos autores. Uma encontrou solo fértil e marcou a história e a memória local, enquanto outra não prosperou. É certo que uma obra de poesia não possui (e nem almeja) uma capacidade de "representância histórica" (RICOEUR, 2007, p.250), mas quando Almeida Junior fala que o "machado progressista" do colono está colocando em risco uma determinada forma de viver particular da região serrana, abre um espaço para uma observação histórica do modo de vida dos caboclos, buscando preservar sua relação com a natureza (seu meio de vida, expresso no poema), e, particularmente, sua forma de falar, sua linguagem.

$\mathrm{Na}$ dissertação de Mestrado Modernização do espaço urbano e patrimônio histórico: Passo Fundo/RS (KNACK, 2007) e no artigo Questões sobre o patrimônio histórico de Passo Fundo/RS: 1990-2002 (KNACK, 2013), foram pesquisados os discursos que orientaram a seleção dos bens patrimoniais municipais, quase todos tombados entre o início da década 1990 e 2000 , onde foi identificada uma primazia de elementos relativos às experiências de elites políticas e econômicas em busca da modernização urbana e afirmação política do município como líder regional. Tal situação levou representantes do movimento negro de Passo Fundo a elaboração de um projeto entregado ao poder público que pedia a restauração e criação de um centro cultural de afro-descendentes em uma edificação que serviu como sociedade de auxílio mútuo a descendentes de escravos da região no início do século XX. Nesse projeto consta, como justificativa, a exclusão desse grupo da historiografia local e regional, transparecendo um ressentimento de décadas de silêncio sobre sua participação na história da comunidade. 


\section{A Terra dos Pinheiraes}

A obra Terra dos Pinheiraes (1927), de Xavier e Oliveira4, produzida em função do centenário da fundação do povoado que viria a ser Passo Fundo, tem o objetivo de estabelecer as origens, destacar seus primeiros habitantes e suas ações nos tempos primordiais da cidade, construindo uma filiação ao passado própria e adequada às elites políticas e letradas da década de 1920. A produção historiográfica do "pai da história" passo-fundense se insere em um momento de discussões sobre a construção da história brasileira que ocorreram durante a Primeira República. O próprio perfil do historiador estava em debate e os campos intelectual e político se apresentavam com uma grande intersecção (CORADINI, 2003, p.126-127), como no caso de Xavier e Oliveira, cuja trajetória política e intelectual (como historiador) caminham juntas (GOMES, 2009). Embora essa obra tenha sido publicada nos momentos finais da Primeira República, o perfil do historiador não se constituiu nesse contexto. Ele começa a se maturar nesse período de discussões sobre o papel do historiador e da própria história a ser narrada para o país, suas regiões e cidades. A emergência da República ensejou o repensar dessas questões, como nos "cânones do fazer história" e sobre as formas de "narrativa" de uma "nova história do Brasil." (GOMES, 2009, p.27).

Para Gomes (2009, p.25), a Primeira República foi fundamental para a "conformação de uma escrita da história do Brasil e para a delimitação do perfil do historiador" tendo como pano de fundo uma discussão "sobre ciência e cientificidade." Porém, como Gutfreind (1998, p.29) demonstra, essa ciência, considerada sagrada para o progresso da humanidade, acaba se tornando "profana" e "impregnada de desígnios políticos." Esse elogio aos homens que contribuíram para o conhecimento, abre a obra Terra dos Pinheiraes em uma série de retratos que colocam os "homens da ciência" ao lado das lideranças políticas municipais. Poder político e conhecimento científico lado a lado. Xavier e Oliveira, mesmo antes da década de 1920, se insere nesse contexto onde política e ciência mantém uma relação íntima.

Gutfreind (1998) mostra que no contexto em que a obra em questão foi produzida, a historiografia sulina dividia-se, ou alinhava-se, entre duas

\footnotetext{
${ }^{4}$ Francisco Antonino Xavier e Oliveira nasceu em Passo Fundo em 1876, trabalhou no comércio e em atividades públicas, como recenseamento populacional em 1900, fundação do Hospital da Caridade. Se dedicou a pesquisa histórica de Passo Fundo durante toda sua vida, atuando também como professor em escolas locais, mas também teve atuação política intensa, ocupando cargos como secretário da intendência municipal, vice-intendente municipal (pelo Partido Republicano Rio-Grandense) e juiz distrital, também atuou como advogado.
} 
vertentes de explicações históricas sobre a origem e o início da história no estado: a matriz platina e a matriz lusitana. Como os nomes já sugerem, a primeira orientação procura aproximar a história do estado à esfera de influência da região do Prata, e a outra nega essa relação, destacando a cultura lusitana para explicar a constituição do Rio Grande do Sul. Não cabe no presente trabalho detalhar os elementos que compõem cada "matriz", mas, a partir da análise das obras de Xavier e Oliveira, fica claro que sua tendência mescla elementos de ambas orientações, pois a presença, ou influência, da região do Prata pode ser encontrada na ação dos jesuítas espanhóis, destacada como início da "civilização", mas a ocupação efetiva da região é atribuída aos portugueses ou luso-brasileiros.

Não existe uma preocupação em explicar a origem da cidade a partir de relações com outras regiões do estado, ou mesmo cidades próximas, a não ser quando se trata de relações políticas e geográficas, como definição de fronteiras, emancipações, limites físicos, etc. Essa é uma característica que está presente em trabalhos oriundos das diferentes matrizes a partir da década de 1920, que marca uma historiografia baseada "nos dados geográfico-físicos, mensuráveis e identificáveis, ela cria uma história para o Rio Grande do Sul que permanece no nível da aparência do processo histórico, pela observação." (GUTFREIND, 1998, p.25).

Essas considerações "externas" à produção historiográfica de Xavier e Oliveira estão presentes na composição "interna" de Terra dos Pinheiraes, obra composta por um conjunto de fotografias dos membros das elites políticas locais do presente (1927), e por excertos sobre as personalidades históricas, ou como o autor os chama, os "vultos do passado". A obra apresenta um texto inicial Passo Fundo Antigo Conferencia historico litteraria, com sete páginas, e outro texto, Arvores historicas, que abre a escrita sobre alguns sujeitos que marcaram a ocupação da região em que o município se insere, contém ainda outro excerto sobre o Povoamento de Passo Fundo, e outros dois intitulados A margem das "memorias" de José Garibaldi e Memorias de um Umbu, finalizando com sete páginas de fotografias dos "vultos do passado".

Na capa, logo abaixo do título, aparece escrito: "Série commemorativa do centenario do começo do povoamento do territorio passo-fundense pela gente brasileira civilizada" (XAVIER E OLIVEIRA, 1927). Essa frase já anuncia o processo seletivo que a narrativa se propõe a realizar através do estabelecimento de elementos considerados próprios da "gente civilizada", implicando o esquecimento daqueles que não condizem com esse ideal. Também já estabelece o valor inerente às ações dos sujeitos narrados no livro 
- são as contribuições dos brasileiros civilizados para a origem do povoado. $\mathrm{Na}$ primeira página aparece, sob o título Os que cooperaram para o conhecimento da terra e seu passado, três retratos e uma fotografia, os três logo abaixo do título e a fotografia, maior, abaixo e centralizada. Os três retratos menores abaixo do título são, respectivamente, de Evaristo Affonso de Castro, (autor de obras como Notícia Descriptiva da Região Missioneira e do Gigante Missioneiro: poemeto histórico e geográfico), de Augusto César (conforme consta na legenda, é um explorador do sertão do Uruguay) e de Maximiliano Beschoren (autor de Impressões de viagem na província do Rio Grande do Sul). A foto maior é de Marcelino Ramos, indicado pela legenda como engenheiro chefe da comissão de estudos da estrada de ferro São Paulo Rio Grande e dirigente da comissão que elaborou o primeiro mapa de Passo Fundo, a pedido da Intendência Municipal. São indivíduos que contribuíram de alguma forma para o conhecimento da região, promotores do desenvolvimento urbano e industrial (do progresso, no entendimento de Xavier e Oliveira). Esses homens são exemplos da "gente civilizada brasileira", suas ações conduziram o pequeno povoado de 1827 ao que ele se tornou em 1927. Eles possibilitaram, entre outras ações, o movimento do "machado progressista" do colono. Como Gomes (2009, p.22) indica, essa preocupação em ressaltar a "ciência" como caminho para a modernização do país era uma preocupação nacional e presente no IHGB: "o Brasil não seria moderno, não se tornaria um país civilizado, sem o auxílio da ciência, o novo e fundamental instrumento para qualquer tipo de progresso da humanidade."

A seleção de fotografias de personagens e seus feitos, funções, ações desempenhadas em prol do progresso (o acontecimento), relacionadas a um lugar específico (Passo Fundo e região), constitui peça integrante de uma narrativa relacional entre o visual e o escrito, confluindo para um sentido abrangente da obra, para sua dimensão configurante, diria Ricoeur (1997) Passo Fundo como uma cidade progressista em virtude das ações desses sujeitos que abrem a leitura da narrativa. Depois da página que homenageia os homens que contribuíram para o conhecimento da terra, a segunda página apresenta dois retratos e uma foto sob o título de Intendentes Municipais, aparecendo, no alto e à esquerda, Armando Araújo Annes, o intendente de 1927, e ao seu lado, no alto, à esquerda, Nicolau de Araújo Vergueiro, intendente da gestão anterior, entre 1920-1924. Esses retratos abarcam as funções documento/monumento (LE GOFF, 2003), pois informam os nomes dos últimos representantes do poder executivo municipal e, ao fazerem isso, os inserem na perspectiva da lembrança daquele momento, colocando-os entre os agentes do progresso local. A foto abaixo, com o título Outro aspecto da belleza da terra, mostra o salto do rio Taquari, local da instalação da usina 
hidrelétrica municipal, lugar que além de apresentar uma beleza natural, como o título sugere, é um fator preponderante para a urbanização e projetos de industrializações da região naquele período, a própria legenda da foto informa que o cenário visualizado faz parte da Uzina Municipal. Além dessas fotos, também aparecem juízes e promotores públicos, representando o judiciário local, bem como fotografias dos primeiros intendentes do município. Essa imagens estabelecem uma relação entre os homens do conhecimento e o poder político municipal - o poder local deveria dar continuidade ao trabalho desses vultos do passado.

O início da escrita da história da cidade corrobora esse direcionamento temporal, como está exposto na Oração filial a Passo Fundo: "Justa é, pois, minha veneração pelo teu passado - relicário sacratíssimo que encerra a origem do teu presente e a esperança do teu futuro." (XAVIER E OLIVEIRA, 1927, p.3). Essa articulação das categorias temporais conhecimento do passado para transformar o presente e projetar o futuro está vinculada à construção visual inicial da obra, que abre a sua narrativa homenageando os homens que contribuíram para o conhecimento da região, os eruditos do passado, promotores de ações progressistas, passando pelos sujeitos que marcam o presente e as expectativas implícitas quanto a sua atuação futura. Tal concepção exprime uma experiência temporal que, de acordo com Catroga (2009), está relacionada à época dos historicismos que influenciou a história no século XIX e boa parte do XX, marcando propostas "condicionadas por mudanças sociais provocadas pela industrialização e pela emergência da sociedade de massas." Entre 1900 e 1920, Passo Fundo assistiu a um intenso processo de transformação urbana, com a conclusão da estrada de ferro, calçamento de ruas, embelezamento de praças, crescimento populacional, experiências que marcaram as expectativas, os projetos em torno do futuro não apenas do município, mas de toda a região do planalto. "Neste contexto, a história foi cada vez mais apresentada como um iter, no qual, o conhecimento do passado era premissa fundamental para se entender o presente e transformar o futuro." (CATROGA, 2009, p.14).

Nesse sentido, a obra analisada é construída tendo a percepção de que o passado é peça fundamental para operar transformações no presente, a exemplo de Marcelino Ramos, que buscou conhecer o planalto médio riograndense para atuar sobre ele, para agir no presente, e o valor de suas ações é medido na sua participação no progresso da região. A obra Terra dos Pinheiraes é dedicada a conhecer o passado de Passo Fundo, com a intenção de transformar o presente e projetar o futuro, para que, como o próprio autor destaca, "Possa a luz fulgurante de um progresso immenso e verdadeiro, 
lavado de corrupção e aureolado pelo phanal celeste do Amor universal, guiarte ao destino esplendoroso que te espera!" (XAVIER E OLIVEIRA, 1927, p.3). De forma clara, o início da Oração filial expressa essa percepção do autor:

Terra de meu berço! Eu te amo na simplicidade dos teus dias primitivos, porque foi ahi que tua gente, campeando na vastidão das estâncias solitarias, ou mourejando nos cerrados hervaes, em lucta com o selvicola traiçoeiro e feroz, adquiriu ou desenvolveu as nobres qualidades que deveriam exalça-la depois, através dos feitos impereciveis dos seus grandes expoentes, legando ao futuro esse patrimonio robusto que é tua historia. (XAVIER E OLIVEIRA, 1927, p.3).

A luta foi a afirmação da "gente" (brasileira e civilizada) que compõem os expoentes (a exemplo dos indivíduos que aparecem nos retratos) nos seus "dias primitivos", com seus feitos memoráveis, que compõem a história local, patrimônio que foi legado ao futuro, no caso, para os contemporâneos de 1927, que devem se inspirar nessa origem, nesse conflituoso e difícil começo do povoamento da região, para batalhar no presente. A distância encontra-se reduzida em virtude da narrativa que trata da gênese do povoado exalar um sentimento de pertencimento à comunidade que se está celebrando. Esse sentimento de pertencimento, definido por Catroga (2007) como "quente", de uma forma mais ampla, está associado a uma dimensão paternal presente nesse olhar para o passado a partir de 1927: "será a partir da idéia e do sentimento de pátria que comunidades e grupos narram a história que os identifica (e os constrói) como famílias alargadas e como comunidades étnicos culturais." Essa narrativa geralmente é contada e escrita com uma "linguagem mais lírica, afetiva e interpeladora que a exprime e metaforiza-a como um corpo moral, mítico e místico." (CATROGA, 2007, p.13-14). É como se cada indivíduo que recebeu o legado do passado estivesse ligado a um projeto comum que o carregou até aquele momento e que deve perdurar para as gerações futuras, "o diálogo entre presente e o passado quase anula o distanciamento entre o sujeito e o objecto" (CATROGA, 2009, p.22).

As fronteiras entre história e memória em um momento de comemoração tornam-se fluídas, e, em relação à Terra dos Pinheiraes, a narração procura instituir um passado comum à comunidade, destacando seus agentes, suas ações com os seus valores que devem ser legados e servir de exemplo ao presente e embasar os projetos da cidade para o futuro. Sua narrativa é uma linguagem "pública" e comum daquele período. Embora Xavier e Oliveira fosse integrante de uma elite política e letrada de Passo Fundo, sua linguagem e suas reflexões não alcançam grandes discussões sobre teoria, o autor não utiliza conceitos próprios de uma ou outra corrente teórica. Sua intenção reside justamente na pesquisa/construção da história da região e seu acesso a um grande público. 
Ao assumir determinada concepção sobre as categorias temporais (passado, presente e futuro), a obra (e o leitor) se alinha a um determinado regime de historicidade que marcava o contexto (seu espaço de experiência) em que o autor a escreveu e que delimitava seu horizonte de expectativa. Nesse tipo de exaltação de Xavier e Oliveira, que estende seu sentimento de pertencimento, de habitante (no sentido de habitar a casa) da cidade, sua afeição por Passo Fundo mescla-se com o regime de historicidade que caracteriza suas obras, especialmente nas "descidas para o passado":

\footnotetext{
Se, com um passo solitário, devaneando, numa casa que traz os grandes signos da profundidade, descemos pela estreita escada obscura que enrola seus altos degraus em torno do eixo de pedra, logo sentimos que descemos a um passado. Ora, para nós não há nenhum passado que nos dê gosto de nosso passado, sem que logo se torne, em nós, um passado mais longínquo, mais incerto, esse passado enorme que já não tem data, que já não sabe as datas de nossa história. (BACHELARD, 1990, p.96).
}

A busca incessante pelas origens, em um momento de comemoração como em 1927, possibilita uma dilatação entre passado, presente e futuro, leva a um momento que não pode ser datado, pois é "longínquo", profundo, e não pode ser encontrado documentos e/ou vestígios históricos. Nenhum documento antigo vai atestar sua veracidade, o que legitima essa aurora das origens é o sentimento íntimo do autor. Esse regime de historicidade (calcado nos sentimentos pátrios saudosistas de Xavier e Oliveira), essa percepção do encadeamento das categorias temporais influenciou a seleção dos elementos que passaram a figurar como centrais para a história e memória da cidade em 1927. Por exemplo, o estabelecimento da origem do município envolvendo a luta entre o "silvícola traiçoeiro e feroz" e a gente brasileira civilizada. Essa diferenciação é típica do período, especialmente se levarmos em conta a tendência do positivismo adotada pelo PRR, do qual Xavier e Oliveira fazia parte, que considerava objetivo da sociedade alcançar o progresso pela urbanização e industrialização (dentro da ordem política e social). Existe aqui uma classificação baseada em uma diferenciação temporal vertical entre sociedades, como Hartog (2006) advertia ao se referir a Lévi-Strauss - existem, segundo o autor, diferenças no modo de ser e no modo como as sociedades tomam consciência e percebem o tempo, mas não no tempo, como se uma estivesse à frente da outra. Nesse sentido, em Terra dos Pinheiraes, o mundo urbano, ordenado, posteriormente industrializado, está no topo da escala social (e temporal), enquanto aqueles indígenas primitivos, que resistiram à ocupação dos "civilizados", estão na base do desenvolvimento (a diferenciação ocorre no tempo, e não no espaço - uns estão na frente dos outros, no sentido de estarem mais "avançados"). Também será realizada uma distinção entre os 
próprios indígenas que se submetem às reduções jesuíticas e aqueles que resistiram ao seu domínio. Xavier e Oliveira inicia o Passo Fundo Antigo Conferencia historico-litteraria com a seguinte passagem:

Si quizermos revêr uma dessas lembranças materiaes que costumamos guardar
como vestigios ou, antes, como cinzas de gratas emoções que no passado
andaram por este orgam que vive a bater em nosso peito, e nelle se extinguiram
deixando-o para sempre embebido no seu perfume suavissimo, que é a saudade
- sentimento cuja natureza celéste a palavra humana até hoje foi mesquinha para
definir sequer de modo aproximado, - mister se torna que busquemos o
compartimento da nossa casa, em que a mesma lembrança esteja, e, ahi, a
retiremos do escrinio em que foi posta para que mãos indiscretas lhe não
tocassem ferindo a santidade do nosso culto. (XAVIER E OLIVEIRA, 1927,
p.4).

Partindo da argumentação de Catroga (2007) sobre os sentimentos pátrios quentes que levam os sujeitos a tecer narrativas sobre o passado comum (o patrimônio espiritual) da comunidade, e de Bachelard (1990, 2008) sobre o imaginário da casa (associada à imagem de criar raízes na terra, como uma árvore), é possível observar que Xavier e Oliveira deixa transparecer seu empenho e afetividade relacionados ao seu ofício de historiador da cidade, ressaltando uma característica que aparece em seus escritos com frequência - o saudosismo, mesclando suas lembranças do passado com sua produção historiográfica. É importante notar a relação entre memória, história e imaginação nessa passagem. A intenção desse texto inicial (a Conferencia historico-litteraria) na obra é realizar um estudo sobre o início da ocupação de Passo Fundo, que, como ele mesmo destaca, implica "uma descida aos fundos tenebrosos dos seculos, para de lá voltarmos acompanhando a marcha de nossa terra para o futuro" (XAVIER E OLIVEIRA, 1927, p.4), mas começa tal escrita afirmando uma relação entre "lembranças materiaes que guardamos como vestígios." O historiador faz uma analogia entre a cidade e sua casa (de onde ressalta esse sentimento quente de fundo patriótico), por isso entende essa descida ao passado remoto como uma busca por lembranças, vestígios, "rastros" dessa história narrada como se ele mesmo (e o leitor que leu em 1927) tivesse vivido esse tempo "intemporal" - o tempo da origem, quase mitológico e com um ar místico - diminuindo a distância temporal imposta pelo tempo cronológico inerente à escrita da história.

Xavier e Oliveira se coloca como um filho da terra (alguém que tem uma raiz, uma ligação com o solo), tendo Passo Fundo como sua grande habitação, que acolhe todos seus conterrâneos em suas belezas naturais, protegendo-os a partir das ações de seus personagens históricos, seus heróis, como mostram seus feitos eternizados como acontecimentos marcantes do "patrimônio robusto que é sua história." Para Bachelard (2008), nossos 
sentimentos de "bem estar" (onde poderíamos incluir os sentimentos de pertencimento a uma comunidade, de ter raízes comuns, de fazer parte de uma história) possuem um passado (uma historicidade própria), e todo passado evocado pela lembrança "vem viver, pelo sonho, numa casa nova", essa evocação tem sucesso em virtude de sua associação com a imaginação. "Nunca somos verdadeiros historiadores; somos sempre um pouco poetas, e nossa emoção talvez não expresse mais que a poesia perdida." (BACHELARD, 2008, p.26). Essa casa, que aparece na escrita a partir da imaginação do autor, se torna uma força de proteção para seus habitantes:

Não é um simples cenário onde a memória reencontra suas imagens. Ainda
gostamos de viver na casa que já não existe, porque nela revivemos, muitas
vezes sem nos dar conta, uma dinâmica de reconforto. Ela nos protegeu, logo,
ela nos reconforta ainda. O ato de habitar reveste-se de valores inconscientes,
valores inconscientes que o inconsciente não esquece. Podemos lançar novas
raízes do inconsciente, não o desenraizamos. Para além das impressões claras e
das satisfações grosseiras do instinto do proprietário, há sonhos mais profundos,
sonhos que querem se enraizar. (BACHELARD, 1990, p.92).

Essa relação entre pátria, terra e saudosismo, é marcante e recorrente nas obras de Xavier e Oliveira. Na análise da narrativa, podemos caracterizar esse processo como uma "ficcionalização da história" (RICOEUR, 1997), pois são introduzidos elementos "ficcionais" para narrar a origem do povoado. Esta ficcionalização é operada pela imaginação do autor (e do leitor). Sua linguagem não é meramente a do historiador, preocupado em narrar fatos, estabelecer datas, personagens e lugares importantes da história. Ao buscar estabelecer as origens de sua grande casa, Xavier e Oliveira experimenta uma espécie de saudades de um tempo, de um momento que não vivenciou, mas, a partir da constelação do imaginário que o envolve, como uma espécie de "atmosfera", um "estado de espírito" (MAFFESOLI, 2001, p.75), consegue expressar esse sentimento envolto no início da jornada de sua comunidade, trazendo-o a 1927.

Esse saudosismo, que relaciona lembranças e a história da comunidade, levando à exaltação da cidade, é uma espécie de "recurso" literário, ou, concordando com Ricoeur (1997), uma ficcionalização que objetiva tornar inteligível sua intencionalidade - narrar a origem do povoado, a ação dos primeiros civilizadores, e toda a emoção e admiração que desperta no narrador se debruçar sobre esse passado. Hartog (2000, p.8) entende esses recursos literários, que, para o presente trabalho, estão associados à noção de ficcionalização da história, não apenas como um estilo, mas como "estruturas narrativas, cuja utilização e composição permitem fazer aparecer e fazer transmitir inteligibilidade, ou mais inteligibilidade. Recursos cognitivos, então, 
para ver e fazer ver o que aconteceu." Essa visão sobre o que aconteceu, para Xavier e Oliveira, não recai apenas naquilo que os rastros podem transmitir, mas também no seu próprio devaneio sobre o que está escrevendo. $O$ saudosismo, mesmo envolvendo um tempo que não vivenciou, objetiva "fazer ver" sua admiração sobre o passado de Passo Fundo e região.

$O$ poder da imaginação posta em movimento impulsiona seu saudosismo que rege sua escrita da história, e concordando com Ricoeur (1999, p.88), as modalidades de representação do ausente, seja essa ausência o "passado real" ou "irreal", utilizam recursos narrativos comuns, como, por exemplo, uma temporalidade que orienta a seleção dos elementos que compõem a trama da narrativa - os lugares, os sujeitos e os acontecimentos aspectos ficcionais e históricos mesclam-se em uma mesma narrativa. Dentro dessa perspectiva, a narrativa de Xavier e Oliveira pode ser tomada como uma interpretação de sentimentos, sonhos, objetivos e questões inquietantes que marcavam a "atmosfera" da época, o que levou o autor a buscar explicações que alinhavam sua experiência enquanto intelectual/historiador e poeta. Ambas estão na órbita de uma consciência de si no tempo como resultado e herdeiro das ações dos antepassados (os sujeitos históricos da narrativa). $\mathrm{O}$ passado é fundamental para essa percepção, assume importância em virtude da transmissão e um legado a ser continuado, já o presente aparece como um entremeio, um momento de passagem para um futuro glorioso. Naquele universo comemorativo, a explicação histórica não bastava, era necessário dar continuidade a tais ações, abrindo um horizonte de expectativas positivo em torno do futuro de Passo Fundo, cidade destinada a grandes e heróicos feitos à semelhança daqueles realizados no passado.

Assim, o autor segue sua narrativa sobre a origem da cidade com a ação dos jesuítas: "phantasiamos uma viagem á busca do caminho que eles, os Padres referidos, sahindo das suas reduções do Paraguay, tinham trilhado para chegar a esta banda [...]." (XAVIER E OLIVEIRA, 1927, p.4). Os jesuítas são selecionados como pioneiros da civilização na região (os primeiros sujeitos da história). Depois o autor descreve a fundação (estabelecendo um lugar e um acontecimento histórico inicial) dos Sete Povos da Margem Oriental do Uruguay, "acompanhando a vida e marcha dos mesmos, seus costumes, questões e luctas, e finalmente sua queda, o seu tombo definitivo" a partir da guerra que "Portugal e Espanha lhes levaram" de "1755 a 1756." (XAVIER E OLIVEIRA, 1927, p.5).

A ação dos "coroados", descendentes dos "tupys", dos quais os guaranis tinham "pavor", e que eram "representantes da terrível nação que tanto sobressaltou os primeiros dias do povoamento de Passo Fundo pela 
corrente brasileira civilisada", aparece como um entrave para o estabelecimento da civilização. Com a queda das reduções do tape, explica o autor, o território "missioneiro foi transformado em domínio dos referidos índios coroados" e com "o exodo que assim se verificou, das ultimas populações guaranys da nossa região, apagavam-se nella os derradeiros lampejos da obra dos Padres da Companhia." (XAVIER E OLIVEIRA, 1927, p.7-8). Depois da "epopeia" jesuítica, o autor chega até o início do século XIX. Apenas cita, brevemente, a passagem da independência até chegar à proclamação da república. Nesse ponto, ressurgem as evocações patrióticas do autor voltadas ao município, considerado como "altar quotidiano do culto sagrado da Patria", entendido como a base da organização nacional: "Céllula da vida do paiz, o município deve merecer o affeto mais carinhoso, o devotamento mais alto que lhe possamos dar." (XAVIER E OLIVEIRA, 1927, p.9).

Além de justificar sua atenção à história local pelo patriotismo, atribuindo um valor para suas contribuições históricas, também indica que, rendido o culto à altura da cidade, seu destino, seu prognóstico, será grandioso, alimentado pelo afeto e carinho de seus munícipes. Para Xavier e Oliveira, é "nas tradições da nossa raça e na história de nosso paiz" que devemos buscar convicção inabalável e aptidão para o "progresso", e na "esmeralda dos nossos campos bordado de flores se retrata a esperança vivaz do nosso futuro, coberto pelo céo de turqueza que serve de pallio a nossa actividade moral e material cada vez crescente." (XAVIER E OLIVEIRA, 1927, p.9-10). A linguagem lírica "antropomorfiza, tanto o território, transformando-o em paisagem, como a população, que se metamorfoseia numa comunidade fraternal de com/patriotas." (CATROGA, 2007, p.22). Finalizando a Confferencia hstorico-litteraria com a eleição de um "valor eterno" e "intemporal" - o patriotismo como propulsor da história e dos prognósticos futuros, o autor passa a escrever sobre o período da fundação do povoado já no século XIX com o subtítulo Arvores historicas. A árvore é uma imagem poética central para a compreensão do sentido, da configuração que Xavier e Oliveira confere à sucessão de acontecimentos que compõem sua narrativa. Bachelard (1990, p.230) descreve a "raiz" dessa imagem, desse sentimento:

A imaginação captava então todas as forças da vida vegetal. Viver como uma árvore! Que crescimento! Que profundidade! Que retidão! Que verdade! No mesmo instante, dentro de nós, sentimos as raízes trabalharem, sentimos que o passado não está morto, que temos algo a fazer, hoje, em nossa vida obscura, em nossa vida subterrânea, em nossa vida solitária, em nossa vida aérea. A árvore está, em toda parte ao mesmo tempo. A velha raiz - na imaginação não existem raízes jovens - vai produzir uma flor nova. A imaginação é uma árvore. Tem as virtude integrantes da árvore. É raiz e remagem. Vive entre o céu e a 
terra. (BACHELARD, 1990, p.230).

"A árvore é um estabilizador, um modelo de retidão e firmeza" (BACHELARD, 1990, p.243), ao estabelecer suas raízes em um solo, as árvores constroem a estabilidade. Quanto mais fundo penetra na terra, maior é a árvore, mais antiga, assim como sua história, chegando aos recantos mais longínquos do passado. Porém, suas raízes fazem mais do que apenas "estabilizar" a história, vincular o homem na terra dos seus antepassados. Elas fazem a árvore crescer, atingir as alturas, nesse caso, a pátria, o país, entendido como uma grande comunidade que paira sobre os munícipes. Esse trecho, Arvores historicas, narra o estabelecimento do primeiro rancho fundado em Passo Fundo. Inicia sua narrativa descrevendo o trajeto do trem que vem de Santa Maria, passando por Pinheiro Machado, onde é possível contemplar, conforme sua descrição, próximo a um cemitério que data do início da ocupação da "gente brasileira civlisada", um "grupo de arvores cuja disposição faz suppôr que sejam sobreviventes de moradia que o tempo extinguisse e de longa data já, porque de casas e bemfeitorias, si existiram, vestigios não apparecem lá." Nesse local, em 1827, o "Alferes Rodrigo Felix Martins [...] ergueu o estabelecimento da sua vasta estância obtida em 1824 por concessão do commando de S. Borja." (XAVIER E OLIVEIRA, 1927, p.11).

O estabelecimento dessa primeira fazenda enfrentou a ira dos "índios coroados ou bugres", que impediram o Alferes de tomar posse em 1824, o que só ocorreu em 1827. Em 1835, quando "sobreveio a revolução", o alferes se muda para Curitiba. Faleceu em 1851, deixando a terra para seus herdeiros. "Tal é a historica pagina que encerram as velhas arvores, quase centenárias, cuja contemplação inspirou estas linhas rememorativas." (XAVIER E OLIVEIRA, 1927, p.12). Tal passagem traz novamente a questão das relações entre memória, imaginário e história. A partir da observação de um lugar, mais precisamente das árvores desse espaço e de uma tapera, o autor "rememora" a fundação do primeiro rancho de Passo Fundo. Certamente não viveu na década de 18205, porém, ao afirmar que suas considerações são frutos de uma rememoração, Xavier e Oliveira mostra a proximidade de seus escritos com

\footnotetext{
5 Uma das poucas fontes que Xavier e Oliveira apresenta é Francisco Xavier de Castro (seu avô) "que conhecia estas plagas desde 1822, nellas veiu residir em 1843 e falleceu, em 1908, com a avançada idade de 99 annos, na sua fazenda Tres Capões, situada no $1^{\circ}$ districto." (XAVIER E OLIVEIRA, 1927, p.12). Tendo como referência a "narrativa" (expressão utilizada por Xavier e Oliveira) de um antigo morador, é possível afirmar que a memória está intimamente relacionada com tal descrição, seja pelas lembranças de Castro, que narrou tais acontecimentos, ou pelas lembranças do próprio historiador, que não menciona ter transcrito a narração de seu passado.
} 
suas próprias memórias. Em determinado momento de contemplação, de devaneio, de fantasia sobre aquele local, o autor conseguiu visualizar, a partir de sua imaginação, aquela tapera sob as árvores. Esse momento de contemplação, envolvido na atmosfera do imaginário, é que é rememorado pelo historiador e passa a entrar nas páginas da história local. Sobre o começo do povoado, os relatos de Francisco Xavier de Castro figuram como principal referência:

O subsídio mais importante que temos sobre este ponto é a informação do mesmo Francisco Xavier de Castro, que nos relatou que, depois de alguns annos de permanencia nos hervaes da Palmeira e em viagens que dos mesmos fizera a fronteira sul, onde ia vender a herva que fazia e com o producto respectivo comprar animaes, - indo de regresso para sua referida comarca de Curityba, ao passar pelo Jacuhysinho aquem de Pinheiro Machado, lá encontrou, recentemente erguido, o rancho do Alferes Rodrigo Felix Martins; e que, proseguindo na sua viagem, quando alcançou a Estância Nova, entre Carasinho e Pulador, na mesma se estava cobrindo o rancho de Alexandre da Motta; sendo que ahi teve sciência de que no Pecegueiro já estava arranchado Bernardo Paes. (XAVIER E OLIVEIRA, 1927, p.24).

Algumas das principais informações sobre a fundação da cidade estão baseadas nas memórias de um morador, um interlocutor de Xavier e Oliveira e nas suas próprias lembranças. Esses sujeitos indicados como fundadores, como primeiros moradores, são estabelecidos a partir de um processo de seleção operado, em parte pelas leituras e pesquisas do historiador, mas também pelas suas próprias lembranças. Essa relação é solidificada pelo imaginário presente que envolve sua descrição das paisagens e lugares que assinalam a origem e o começo do povoado. A datação, a construção de um tempo crônico é introduzida depois que um "tempo da lembrança" aparece na narrativa.

A memória e o imaginário assumem uma potencialidade configuradora da obra, não apenas por revelar seu sentido geral, por conferir um ritmo à leitura engendrado pelo seu regime de historicidade, mas ao próprio fazer historiográfico, ao momento de pesquisa, de leitura e interpretação de rastros anterior à escrita, e à própria escrita, na narrativa que tem início a partir das considerações do autor sobre a saudade dos tempos primordiais e o culto patriótico que devemos render ao município. E, embora memória e história guardem a semelhança de aspiração à "verdade" (uma pelos documentos e outra pela fidelidade do que se está lembrando), "se esta característica a distingue da imaginação, convém lembrar, porém, que ambas convocam um objeto ausente." (CATROGA, 2001, p.47). Para exemplificar o papel da memória e da imaginação, basta observar o início o trecho Memórias de um Umbu: 
Á semelhança do vetusto pinheiro de Guarapuava, em cuja contemplação a mente imaginosa de Luiz Cleve poude reconstituir e vêr desfilarem magestosamente os grandes factos da historia daquella região, talvez o mais velho dos umbus da alta coxilha á margem direita do Pinheiro Torto, na estrada desta cidade ao Pulador, pudesse relembrar muita cousa importante do nosso passado, desde que fosse argúido pelo mesmo processo de evocação. (XAVIER E OLIVEIRA, 1927, p.28).

A contemplação da natureza esparrama a imaginação do autor pelo espaço observado, é a propulsão da narrativa. Os sentimentos patrióticos, expressados em uma linguagem "lírica, afetiva e maternal", conduzem a uma "anrtropomorfização" do território, "transformando-o em paisagem." (CATROGA, 2007, p.22). O recurso à imagem da árvore (que confere título à obra) que contempla a história é fruto dessa antropomorfização do território impulsionada pelo civismo. Para Bachelard (1990, p.230), "a árvore é um objeto integrante" associada à ideia de estabelecer "raiz" na terra. Por isso a ideia da terra como berço da pátria, como uma espécie de casa primordial de seus habitantes, onde estão suas raízes - "a raiz é um eixo da profundidade". Essa imagem poética funciona tanto como um recurso literário ficcional da narrativa, quanto um elemento indispensável para sua compreensão, que passa a exigir um esforço imaginativo por parte do leitor. "Embebido nesta idéia, nosso pensamento vôou para a referida coxilha, e lá, depois de adejar em torno á venerada arvore e saudala com justa emoção, dest'arte lhe falou:"

Velho umbú de minha terra: conta-me o teu passado, diz-me o que tens visto
desta eminencia em que ha tantos anos te contemplo e, antes de mim, por
deceníos te contemplaram outros. - Nasci ao sol dos primeiros dias da historia
de Passo Fundo, no tempo em que uns homens de rijo aspecto e não menos
sólido caracter, da comarca de Curityba uns, da fronteira sul outros, começaram
a chegar a estes campos e a plantar nelles o seu dominio. (XAVIER E
OLIVEIRA, 1927, p.28).

O umbu assume o papel de sujeito histórico, como um morador que tece um relato sobre suas experiências passadas. Também revela, novamente, o saudosismo, a nostalgia que envolve a escrita da história de Xavier e Oliveira, sua vontade de observar e sua admiração sobre tempos remotos, que antecedem seu tempo vivido, tornando a comemoração da fundação do povoado "um culto nostálgico e regressivo", mas por outro lado, "o passado é reinterpretado à luz da lição que se pretende dar ao presente e ao porvir." (CATROGA, 2009, p.52). Segue assim a narrativa, como se o umbu estivesse contando aquilo que viu, desde viajantes levando carretas e bois, até os "desfiles" nas "guerras de 1852, contra Rosas; de 1864, contra o governo do Estado Oriental, e de 1865 a 1870, contra Lopes, de guardas nacionais." Os conflitos civis também são observados pelo umbu: "mergulhando em funda 
tristeza, contemplei tambem nas guerras civis de 1835 a 1845; 1892 a 1895 e finalmente em 1923 - quinze anos de lutas fratricidas em 9 decennios." Além das guerras, também é citada a construção da estrada de ferro, finalizada em 1898, "depois disso, vi, ainda, a construcção do telephone para Carasinho; a luz electrica na cidade; a passagem do primeiro automovel", sem esquecer $\mathrm{o}$ primeiro aeroplano em 1920. (XAVIER E OLIVEIRA, 1927, p.30).

A partir desse dia, nada mais vi que me impressionasse; mas a minha
contemplação subsiste, e espero que a infinita bondade de Deus, que me creou e
tem me nutrido até hoje, me permitirá contemplar ainda largo trecho da vida de
Passo Fundo, caracterisado pela maxima felicidade e gloria do seu povo.
(XAVIER E OLIVEIRA, 1927, p.30).

A nostalgia é marcante no relato do umbu, chegando até 1920, quando nada mais interessante foi contemplado. Parte do relato da árvore pode ser atribuída à própria observação do autor, especialmente a partir do momento em que passa a descrever as transformações urbanas, como a instalação da estrada de ferro, a passagem do automóvel e do aeroplano, que já aparecem com datas específicas (dia, mês e ano - acontecimentos "objetivados" em um tempo crônico). Essa modernização desencadeada nas primeiras décadas do século XX, embora ateste o progresso municipal (que deve continuar a ser contemplado no futuro), está envolvida no saudosismo do passado. Resulta da ação dos sujeitos históricos e de seus feitos "gloriosos". Pensar na origem do povoado, naqueles que figuram entre os primeiros a se estabelecerem, é uma maneira de "domesticar a aceleração do tempo presente e ancorá-lo num passado" (MONTEIRO, 2006, p.58). Huyssen (2014, p.91) caracteriza a nostalgia como uma "saudade de um passado perdido" que acabou se transformando em uma "doença" com a emergência de uma nova temporalidade a partir do século XVII.

\section{Considerações finais}

De fato, o olhar de Xavier e Oliveira é nostálgico, a historicidade que marca sua narrativa tem esse teor, porém não é carregada de negatividade, não se configura como uma "doença" (talvez uma melancolia). O historiador não abandona, nesse caso, a noção linear de progresso cara a sua formação no seio do PRR, especialmente porque muitas de suas ações enquanto político contribuíram para isso, como o relato do Umbu demonstra. Sua melancolia provém do seu próprio saudosismo em relação ao passado da cidade, que é mesclado ao de sua própria família. Como o historiador vai ancorar o presente no passado, a forma de filiação, depende do regime de historicidade em que 
seu trabalho se inscreve. Nesse caso, os vínculos entre presente e passado são tecidos sob um olhar nostálgico, mas que não envolve necessariamente uma reprovação, ou uma perda no presente, mas sim uma admiração da história que está sendo narrada que leva a um otimismo em relação ao futuro, entendendo o progresso como natural e inevitável para a sociedade.

Visão que se distancia daquela conexão entre sujeito e natureza presente no Puchirão do Gé Picaço, observando no caboclo um personagem simplório, vivendo em um ambiente idílico e pitoresco, que preserva formas de relações de trabalho distantes do ideal de progressista que alimentou as operações de seleção da história de Xavier e Oliveira. As duas obras se distanciam também em relação ao papel do conhecimento. Enquanto a ciência e a técnica são observadas como fundamentais para o progresso (a seleção e homenagem prestadas pelas fotografias) em Terra dos Pinheiraes, Simão valoriza o conhecimento advindo da experiência dos caboclos com a terra, os saberes cotidianos transmitidos de geração para geração, ou com o exemplo da própria prática. As duas obras diferem, especialmente, em relação ao progresso e a modernização urbana. Elementos que se distanciavam da "civilização" e do progresso da história praticamente não aparecem na narrativa de Xavier e Oliveira, enquanto com Simão, além do progresso ser entendido como uma força que transforma a paisagem, também é visto como o ocaso de um modo de vida próprio do planalto médio riograndense e dos caboclos da região. Enquanto esse mundo que aparece no poemeto serrano praticamente desaparece das narrativas históricas da cidade, a visão de Xavier e Oliveira encontra solo fértil6 e suas obras se tornam uma referência sobre a história e a cultura local, deixando nas margens da história indígenas, caboclos e escravos, sujeitos que não condiziam com os ideais progressistas e patrióticos que passou a impregnar a memória histórica municipal.

${ }^{6}$ Xavier e Oliveira foi homenageado pelo Instituto Histórico de Passo Fundo durante as comemorações do centenário municipal em 1957, quando é reconhecido como o "pai da história de Passo Fundo", tendo quatro obras publicadas com auxílio do instituto e da prefeitura naquela ocasião. 


\section{Referências}

AYRES, Odilon Garcez. O caboclo serrano em $\mathbf{O}$ puchirão do Gé Picaço nas revoluções de 1923, 30 e 32. Passo Fundo: Méritos, 2008.

BACHELARD, Gaston. A terra e os devaneios do repouso: ensaio sobre as imagens da intimidade. São Paulo: Martins Fontes, 1990.

BACHELARD, Gaston. A poética do espaço. $2^{\circ}$ ed. São Paulo: Martins Fontes, 2008.

CANDAU, Joël. Memória e identidade. São Paulo: Contexto, 2011.

CATROGA, Fernando. Memória e história. In: PESAVENTO, Sandra Jatahy. (org.). Fronteiras do milênio. Porto Alegre: Editora Ed. Universidade/UFRGS, 2001.

CATROGA, Fernando. Pátria e Nação. In: VII Jornada Setecentista, CEDOPE. Curitiba: UFPR, v.1, p.13-34, 2007.

CATROGA, Fernando. Os passos do homem como restolho do tempo: memória e fim do fim da história. Coimbra: Almedina, 2009.

CORADINI, Odaci Luiz. As missões da "cultura" e da "política": confrontos e reconversões de elites culturais e políticas no Rio Grande do Sul (1920-1960). Estudos Históricos, Rio de Janeiro, v. 2, n. 32, p.125-144, 2003.

FERREIRA, Antonio Celso. A epopéia bandeirante: letrados, instituições, invenção histórica (1870-1940). São Paulo: Editora UNESP, 2002.

GOMES, Ângela Maria de Castro. A República, a história e o IHGB. Belo Horizonte: Fino Traço, 2009.

GUTFREIND, Ieda. A historiografia rio-grandense. 2.ed. Porto Alegre: Ed. Universidade/UFRGS, 1998.

HARTOG, François. A fábrica da história: do "acontecimento" à escrita da história as primeiras escolhas gregas. História em revista, Pelotas, v. 6, p. 7 19, dez 2000.

HARTOG, François. O olhar distanciado: Lévi-Strauss e a história. Topoi, Rio de Janeiro, UFRJ, v. 7, n. 12, p.9-24, jan-jun 2006. 
HARTOG, François. Regimes de historicidade: presentismo e experiências do tempo. Belo Horizonte: Autêntica Editora, 2013.

HUYSSEN, Andreas. Culturas do passado-presente, artes visuais, políticas da memória. Rio de Janeiro: Contraponto/ Museu de Arte do Rio, 2014.

KNACK, Eduardo Roberto Jordão. Modernização do espaço urbano e patrimônio histórico: Passo Fundo/RS. 2007. Dissertação (Mestrado em História) - Programa de Pós-Graduação em História, Universidade de Passo Fundo, Passo Fundo, 2007.

KNACK, Eduardo Roberto Jordão. Questões sobre o patrimônio histórico de Passo Fundo/RS: 1990-2002. Mouseion, Canoas, n. 14, p.21-36, jan-abr 2013.

LE GOFF, Jacques. História e memória. 5. ed. Campinas: UNICAMP, 2003.

MAFFESOLI, Michel. O imaginário é uma realidade? Revista FAMECOS, Porto Alegre, v. 8, n. 15, p.74-82, ago 2001.

MONTEIRO, Charles. Porto Alegre e suas escritas: história e memórias da cidade. Porto Alegre: EDIPUCRS, 2006.

MONTEIRO, Paulo. O Puchirão do Gé Picaço - Poemeto Serrano Resposta Literária a Antonio Chimango - Poemeto Campestre. 2010. Disponível em: <www.projetopassofundo.com.br> Acesso em: 18 out. 2010.

MURARI, Luciana. Natureza e cultura no Brasil. São Paulo: Alameda, 2009.

MURARI, Luciana. A construção da identidade social na literatura regionalista: o caso sul-rio-grandense. Anos 90, Porto Alegre, v.17, n. 32, p. 159-183, dez. 2010.

NICOLAZZI, Fernando. Uma teoria da história: Paul Ricoeur e a hermenêutica do discurso historiográfico. História em revista, Pelotas, v. 9, p.1-16, dez. 2003.

RIBAS, João Vicente. A representação gauchesca do município de Passo Fundo. 2007. Dissertação (Mestrado em História) - Programa de PósGraduação em História, Universidade de Passo Fundo, Passo Fundo, 2007.

RICOEUR, Paul. Tempo e narrativa. Tomo 3. Campinas: Papirus, 1997.

RICOEUR, Paul. Quelques réflexions sur l'intitulé du séminaire. In: DOUGIER, Henry (org.). Travail de mémoire 1914-1998 Une nécessite dans un siècle de violence. Paris: Éditions Autrement, 1999. 
RICOEUR, Paul. A memória, a história, o esquecimento. Campinas: Editora da Unicamp, 2007.

SIMÃO, Julio. O Puchirão do Gé Picaço (Poemeto Serrano). Passo Fundo: Livraria Nacional, 1925.

XAVIER E OLIVEIRA, Francisco Antonino. Terra dos Pinheiraes. Passo Fundo: Livraria Nacional, 1927.

\begin{abstract}
The following study focus on elucidating the history's operations of selection, of Passo Fundo's memory and imaginary based on two literary works written during the '20s: O Puchirão do Gé Picaço, a collection of poems written by the lawyer and journalist Francisco de Paula Lacerda de Almeida Júnior, and Terra dos Pinheiraes, written by the historian Francisco Antonio Xavier e Oliveira. From a detailed analysis of these two works, it is possible to notice two different narratives that establish different ways of association with the past, as well as different approaches to subjects, places and events that are important for these two distinct ways of relation with the history and memory of the city. These choices were operated from a particular regime of historicity on that context, highlighted by the idea of progress and the urban modernization, which posed a strong influence in the affirmation and success of a literary style in the history of the city.
\end{abstract}

Keywords: History. Memory. Narrative. 